\title{
Study on establishment of Body of Knowledge of Taiwan's Traditional Wooden Structure Technology
}

\author{
M.T. Huang ${ }^{\text {a }}$, S.C. Chiou ${ }^{\text {a }}$, T.W. Hsu ${ }^{\text {a }}$, P.C. Su ${ }^{\text {b, }}$ \\ ${ }^{\text {a }}$ Graduate School of Design, National Yunlin University of Science \& Technology, Yunlin County, Taiwan, Republic Of China - \\ humita.tw@gmail.com \\ ${ }^{\mathrm{b}}$ Visual Communication Design, Southern Taiwan University of Science and Technology, Tainan City, Taiwan, Republic Of China
}

Commission VI, WG VI/4

KEY WORDS: traditional timber technology, technology preservation, and knowledge system

\begin{abstract}
:
The timber technology of the Taiwan traditional architecture is brought by the immigrants in the Southern Fujian of China in the early, which has been inherited for a hundred years. In the past, these traditional timber technologies were taught by mentoring, however, due to the change of the social form, the construction of the traditional architecture was faded away, and what is gradually replaced is the repair work of the traditional architecture, therefore, the construction method of the timber technology, use form of the tool and other factors are very different from previous one, and the core technology is faced with the dilemma of endangered loss. There are many relevant studies on architectural style, construction method of technology, schools of craftsman, technical capacity of craftsman and other timber technologies, or the technology preservation is carried out by dictating the historical record, studying the skills and other ways, but for the timber craftsman repairing the traditional architecture on the front line, there is still space for discussing whether to maintain the original construction method and maintain the due repair quality for the core technology. This paper classified the timber technology knowledge with the document analysis method and expert interview method, carried out the architecture analysis of knowledge hierarchy, and finally, built the preliminary framework of the timber technology knowledge system of the Taiwan traditional architecture, and built the standard formulation available for craftsman training and skills identification by virtue of the knowledge system, so that the craftsman did not affect the technical capacity due to the change of the knowledge instruction system, thus, affecting the repair quality of the traditional architecture; and in addition, the building of the database system can also be derived by means of the knowledge structure, so as to integrate the consistency of the contents of core technical capacity. It can be used as the interpretation data; the knowledge is standardized and the authority file is established, which is regarded as a technical specification, so that the technology is standardized, thus, avoid loss or distort.
\end{abstract}

\section{PREFACE}

Since Cultural Heritage Preservation Act was formulated in Taiwan in 1982 and published, the certain procedure and construction qualification shall be required for the relevant specification on the repair of cultural assets, the advantages and disadvantages of technology of the traditional craftsman for repair on the front line are related to the repair degree of the traditional architecture, therefore, it is very important in the technical capacity, technical specification and technological inheritance. In recent years, the repair funds for government to prepare the cultural assets annually have fallen behind the increase quantity designated or logged in by the cultural assets; and in the historical sites or historical building repaired in the early has been faced with the cycle period of repair, therefore, the industrial demands are increased, but due to the industrial structural relationship, the talents are less willing to learn, and the fault crisis is occurred, accordingly, the technology preservation is very important and also corresponding to the industrial demand; and the repair of the cultural assets has become a complete industry chain, and the supply and demand of the industry and talent cultivation should be valued, but no complete specification is not yet built on the legal system.

\subsection{Research motivation}

In the past, the repair craftsman was responsible for dominating everything on the building and repair of the traditional architecture and controlling its quality; however, on the premise of the current decrees, the architect shall dominate, and for the control of the repair quality, the architect constructing the construction firm and taking charge of the design and supervision is taken as the responsibility layer, so that the responsibility of the front-line construction craftsman is reduced, and the improvement and control of the quality was slightly insufficient. Therefore, the repair industry of the whole cultural assets is faced with talent shortage and technical capacity failure, so that the talent level is mixed, thus, causing the threat of whole competitiveness of the repair industry of the cultural assets. So, the problem faced shall be solved by considering from the industrial demand and talent cultivation system.

The structure of Taiwan traditional architecture has diversified kinds, and the structural materials, including the wood, brick, stone and soil, are provided; but there are much many buildings taking the [wood] as the main structural material. The Chinese traditional architectural structure, Japanese architectural structure, western wooden house structure and others are provided. These structures are main structure supporting the building, most of them are public architectural space, and used by the public, therefore, [timber technology] taking the timber structure for building or repair is very important in the repair type of the traditional architecture.

\subsection{Research objectives}

In the past, the traditional timber technology was taught mainly by mentoring, the apprentice studied for 3 years and 3 months aside the maser, and could stay with maser to continue working after finishing apprenticeship, or hold his own outside and undertake work by himself; but as the society is changed and 
the quantity demanded is reduced, the past traditional architecture is [newly built] and now [repaired], and the master undertook from the design, construction and supervision to completion previously, and now, the architect takes charge of the planning and design and supervision, and entrusts the craftsman to construct according to the drawing planned by the architect after the project is undertaken by the construction firm, the timber technology is different from the past traditional item, process, construction method, tool and modern construction, therefore, the system and form formed by the craftsman at the current stage are entirely different form the past ones, thus, causing the traditional architecture knowledge (pole ruler making, construction taboos and ceremony...) of the timber is gradually disappeared.

In recent years, the craftsman dictates the history, records he construction process and carries out the preservation study on relevant technology, but the whole [timber technology knowledge system] is still studied by segments, the structure of the traditional knowledge and newly repaired knowledge should be built in a complete knowledge system, and the knowledge inheritance of [technology] is the most important among it. The knowledge on technology is intangible, and how to focus on the convergence, classification and management of the knowledge through the knowledge transfer, layer the knowledge on the timber technology of traditional architecture according to the structure, carry out the systematic management on the knowledge, define the same and carry out data annotation? The complete knowledge system can make many repair concept and technology standardized and better educated, so that the knowledge inheritance does not have a fall due to the different teaching levels, and then, the repair quality of the traditional architecture is affected, which is the final objective of this study.

\section{LITERATURE REVIEW}

[Knowledge] is learning and known affair. Harris (1996) thought that the knowledge is the combination of cultural inheritance, experience accumulation and information. The cultural inheritance refers to the point that the people's opinion is affected by the religious faith, social value, own personality and sex and other factors; the experience accumulation refers to the experience accumulated by the individual in the life; and the information is produced after the data analysis and interpretation. And in fact, the knowledge system is built for the purpose of carry out [knowledge management]. Hult (2003) also thought that the knowledge management was still a series of organization and systematization procedure, and used for producing and spreading the information, selecting, extracting and transforming the implicit and explicit knowledge, obtaining the unique value, and grasping the competitive advantage. A large number of knowledge shall be managed, and the knowledge classification should be carried out firstly, so as to facilitate the building of the management system; and the knowledge classification refers to divide all knowledge into different kinds of knowledge system by contrasting according to the same, difference, correlation and other properties on the basis of specific demand and standard, and display its proper position and correlation in the whole knowledge.

This study classified and discussed the literature of the traditional timber technology. There were many studies on the knowledge of traditional architecture and its repair knowledge, but for the structure of integrating the traditional construction technology and repair technology into the single technology was discussed very little, therefore, this study tried to classify and discus form the big structure of the building, and discussed the classification of the derived knowledge, hoping to summarize the knowledge structure of its timber technology from the analysis of document content.

\subsection{Classified study of Taiwan's architecture}

Manual of Taiwan Traditional Architecture-Form and Practice (1995, Lin Huicheng) is classified according to the layout, scale, pavement, body of building, roof, decoration, painting, furniture, ornament, exorcising and others on the basis of architectural form and practice. Construction of architectural history in Taiwan: seven culture periods and five orientations (2001, Lin Huicheng) classified the architecture constructed in the different periods in Taiwan into the prehistoric architecture (CA.7, 000 BP-500 BP ) , South Island architecture (CA.6, 000 BP-1970) , Hexi architecture (1622-1670s ), architecture in China Han dynasty (CA.1640s-1950s), western architecture (1860s-2000s), Japanese architecture (1895-1950s), modern architecture (1990s-now) and the like; and the architecture at the different period is classified with the time dating. In the Compilation plan on handbook of vocabulary on historical sites (ancient architectures) and historical architecture (2004, Xu Mingfu ), the relevant vocabulary on ancient architecture in Taiwan takes the transition of architectural format, architectural type, architectural form and practice, space usage, construction system, relevant affairs on architecture, relevant figures on architecture and other seven categories as the main classification; and in addition, the [cultural periods] (such as classification way according to the time dating) is taken as the secondary classification, such classification way refers to take the various orientations as the main classification, classify according to the dating time, and subdivide the crosshead. Such way is even complete. And in Rules for Implementation of Cultural Heritage Preservation Act, the historical sites and historical architecture are classified into ancestral hall, temple, mansion, city wall, passes, government office, station, academy, stone tablet, church, memorial archway, tombs, dike gate, lighthouse, bridge, industrial facilities and the like. Such classification way refers to classify the usage function of the architecture.

\subsection{Classified study of architecture in China Han dynasty}

It can be known from the above the building classification in Taiwan that, the architecture in China Han Dynasty is the type with complete classification currently. In the Survey research on school of traditional construction craftsman (1988, Li Ganlang ), the type of the traditional craftsman, school of building maker and craftsman, Zhangzhou School, Quanzhou School and others are based; and the classification is carried out on the school of the craftsman. In the encyclopedia on diagram of ancient architecture in Taiwan (2003, Li Ganlang), the traditional architecture of the Han culture is completely classified according to the function type, plan layout, part structure, decoration technology, furniture and implements, skills and custom, tool material, school of craftsman and others. In the Study on dwelling house of Taiwan traditional architecture and its local historical data (1990, Xu Mingfu), the local study is carried out on the construction of the definition of traditional dwelling house, local historical data of dwelling house and others. Such study shows the importance of ethnic study and local study, because Taiwan people is mostly immigrants from south Fujian and Hakka area, and the architectural form is different from that of architecture from the south Fujian and Hakka area; and in addition, as the regional 
difference ( such as: Jinmen, Penghu and Matsu ) and [regional studies] are emerged, the difference of regional ethnic group and environment on the architecture belongs to the classification of the ethnic group and regional characteristics.

\subsection{Classified study of establishing technology}

Technology is an important item for the construction, and the technology of the craftsman is even the key concerning the building quality. The documents classified according to the category of technology include Survey research on traditional craftsman in Taiwan and Fujian (phase I) (1991, Hong Wenxiong), Survey research on traditional craftsman in Taiwan and Fujian (phase II) (1993, Hong Wenxiong). The type of technical works of the craftsmen is divided into the carpentry work, soil and water works, joinery work, scabbling, stonemason, pasting of clay sculpture, painting and other seven classifications. In the Survey on traditional craftsman for preservation and repair of buildings.cultural assets and study on cultivation strategy (2007, Lai Zhizhang), it is divided into the carpentry work, soil and water works, joinery work, scabbling, stone hitting, painting, koji pottery of pasting of clay sculpture and other six classifications according to the type of work. In the Plan on maintenance of historical sites, historical architecture and settled cultural landscape and human resource protection of repair craftsman (2010, Xue Qin), the current construction craftsmen of Taiwan traditional architecture is divided into the carpentry work, joinery work, scabbling, soil and water works, stone work, tilework, painting, pasting of clay sculpture and other eight types of work. In the Purchase method for repair and reuse of historical architecture of historical sites and settlement, the traditional craftsman or professional technician is selected for the signal repair of the special technology, wherein the signal repair of the special technology is classified into: 1 . mosaic glass, painting, wall painting, pasting, koji pottery, clay sculpture and scabbling; 2. carpentry work, joinery work, cabinet work and mudwork; 3. stone-slab houses of indigenous peoples, and tilework of Japanese architecture; 4. Other special technologies affirmed by the competent authority. But such classification has not been in conformity to the demand of the repair situation, therefore, it shall be adjusted, so as to conform to the industrial demand.

\subsection{Classified study of traditional knowledge}

Due to adapting to the change of social time, a lot of knowledge on construction of traditional architecture has been gradually disappeared because the repair of the cultural assets is mostly provided, but the relevant classification is also provided for the record of the knowledge. In the Study on regulation of construction size of Taiwan architecture (1980, Xu Yujian) and Comparative study on shape of traditional dwelling house in Jinmen and Penghu-Discussion on taboo, ceremony and decoration during construction (2001, Zhang Yutong), many size regulations, construction ceremony and taboo on the construction are recorded and analyzed. In the Traditional pole falling technology in Taiwan and Fujian (1999, Li Ganlang) and Feasibility study on representation of pole of Taiwan traditional timber structure with digital mode (2009, Lin Yijun ), the technology of building the house traditionally is recorded and discussed with the modern technology.

\section{RESEARCH METHOD}

This research tries to establish a knowledge system of Taiwan traditional carpentry technology, and it has wide application, so the following two research methods are mainly used as the core knowledge classification and knowledge layering structure of traditional carpentry so as to propose specific suggestion t the development direction of the carpentry technology knowledge system structure in the future.

\subsection{Literature analysis}

The literature analysis is a method for obtaining the required data by collecting, analyzing and researching literature and a research method for objectively and systematically describing and quantifying the literature. So is the knowledge system research of [carpentry technology], there are many researches on [carpentry technology], including the research on building form and structure, the research on construction and repair technology, the research on traditional craftsman and development, the research on construction ritual and taboo, the research on craftsman described history, the technology storage and practice, all work reports of repair works. However, there are only few researches on complete knowledge framework of traditional building carpentry technology. Therefore, this research tries to collect and classify the data in all research fields and systematically conclude the layering framework, this is helpful for planning an overall knowledge framework of carpentry technology.

\subsection{Expert interview}

As everyone knows, the interview is an important method for collecting data. It aims to make the interviewer and interviewee to [communicate face to face, and one party tries to understand the thought and feeling of the other party] (Mishler,1986a) and perform the expert interview and mainly hopes to obtain the first-hand correct data from the expert interview, compensate the short of the second-hand data and increase the reference faith of the literature data analysis. Some carpentry technologies are related to the manufacturer, plan design, architect office and related researcher in the fields of cultural asset repair, so this research invites 5 experts to interview with people related to the carpentry technology and cultural asset repair, related people have more than 10 years of experience, the member includes the architect and manager in architect office, the site responsible person in manufacturer, the carpentry craftsman and expert representative (as shown in Table 1) so as to understand the traditional and repair related framework of integral carpentry.

\begin{tabular}{|c|c|c|c|c|}
\hline NO & $\begin{array}{l}\text { POSITION } \\
\text { OF } \\
\text { INTERVIEW } \\
\text { EE }\end{array}$ & SEX & $\begin{array}{l}\text { YEAR } \\
\text { S OF } \\
\text { SERVI } \\
\text { CE } \\
\end{array}$ & SPECIALITY \\
\hline M1 & $\begin{array}{l}\text { MANAGER } \\
\text { OF } \\
\text { BUILDING } \\
\text { OFFICE }\end{array}$ & FEMALE & $\begin{array}{l}\text { ABOU } \\
\text { T } 15 \\
\text { YEAR } \\
\text { S }\end{array}$ & $\begin{array}{l}\text { DESIGN AND } \\
\text { MONITORING } \\
\text { OF REPAIR } \\
\text { PROJECT } \\
\text { PLAN }\end{array}$ \\
\hline M2 & $\begin{array}{l}\text { CARPENTR } \\
\text { Y } \\
\text { TECHNOLO } \\
\text { GY EXPERT }\end{array}$ & MALE & $\begin{array}{l}\text { ABOU } \\
\text { T } 20 \\
\text { YEAR } \\
\mathrm{S}\end{array}$ & $\begin{array}{l}\text { DESIGN AND } \\
\text { MONITORING } \\
\text { OF } \\
\text { CRAFTSMAN } \\
\text { RESEARCH } \\
\text { AND REPAIR } \\
\text { PROJECT } \\
\end{array}$ \\
\hline M3 & $\begin{array}{l}\text { SITE } \\
\text { RESPONSIB } \\
\text { LE PERSON } \\
\text { OF } \\
\text { CONSTRUC } \\
\text { TION } \\
\text { PLANT }\end{array}$ & FEMALE & $\begin{array}{l}\text { ABOU } \\
\text { T } 15 \\
\text { YEAR } \\
\text { S }\end{array}$ & $\begin{array}{ll}\text { CONSTRUCTI } \\
\text { ON } & \text { OF } \\
\text { REPAIR } & \\
\text { PROJECT } & \end{array}$ \\
\hline
\end{tabular}




\begin{tabular}{|c|c|c|c|c|}
\hline M4 & $\begin{array}{l}\text { TRADITION } \\
\text { AL } \\
\text { CARPENTE } \\
\text { R }\end{array}$ & MALE & $\begin{array}{l}\text { ABOU } \\
\text { T } 20 \\
\text { YEAR } \\
\text { S }\end{array}$ & $\begin{array}{l}\text { CARPENTRY } \\
\text { TECHNOLOG } \\
Y\end{array}$ \\
\hline M5 & $\begin{array}{l}\text { TRADITION } \\
\text { AL } \\
\text { CARPENTE } \\
\text { R }\end{array}$ & MALE & $\begin{array}{l}\text { ABOU } \\
\text { T 15 } \\
\text { YEAR } \\
\text { S }\end{array}$ & $\begin{array}{l}\text { CARPENTRY } \\
\text { TECHNOLOG } \\
\mathrm{Y}\end{array}$ \\
\hline
\end{tabular}

Table 1 List of interviewees

\subsection{Research scope and limit}

There are many Taiwan traditional buildings, including the Aboriginal building, Chinese building, Japanese building, Western building, etc. It is required that different building styles have different building knowledge, this research counts that there are 806 historic sites, 1237 historic buildings, 2043 individual basic data (up to May 8, 2015) in the [national culture asset management system] built by the Bureau of Cultural Heritage, in these data, the keywords are shown for 1926 times, currently, most buildings in Taiwan are of Chinese style, so this research is focused on the construction of Chinese building carpentry technology knowledge system, the carpentry technology in other periods will be discussed later.

\begin{tabular}{|c|c|c|c|c|}
\hline No. & Keywords & $\begin{array}{l}\text { Stroke an } \\
\text { of sho } \\
\text { historic } \\
\text { keywords }\end{array}$ & $\begin{array}{l}\text { ount Stroke amount } \\
\text { wing of showing } \\
\text { site historic } \\
\text { building } \\
\text { keywords }\end{array}$ & Total \\
\hline 1 & Carpentry & 92 & 283 & 375 \\
\hline 2 & $\begin{array}{l}\text { Chinese } \\
\text { style }\end{array}$ & 4 & 5 & 9 \\
\hline 3 & $\begin{array}{c}\text { Tenon } \\
\text { through }\end{array}$ & 25 & 39 & 64 \\
\hline 4 & $\begin{array}{c}\text { Tenon } \\
\text { alternation }\end{array}$ & 38 & 18 & 56 \\
\hline 5 & $\begin{array}{c}\text { Lifting } \\
\text { beam }\end{array}$ & 31 & 30 & 61 \\
\hline 6 & $\begin{array}{c}\text { Bearing } \\
\text { wall }\end{array}$ & 70 & 96 & 166 \\
\hline 7 & $\begin{array}{c}\text { Wood } \\
\text { framework }\end{array}$ & 223 & 264 & 487 \\
\hline 8 & $\begin{array}{c}\text { Wooden } \\
\text { beam }\end{array}$ & 17 & 23 & 40 \\
\hline 9 & Wood & 165 & 245 & 410 \\
\hline 10 & $\begin{array}{l}\text { bucket } \\
\text { arch }\end{array}$ & 34 & 8 & 42 \\
\hline 11 & ridgepole & 46 & 1 & 47 \\
\hline 12 & $\begin{array}{c}\text { southern } \\
\text { Fujian }\end{array}$ & 83 & 86 & 169 \\
\hline \multicolumn{2}{|r|}{ Total } & 828 & 1098 & 1926 \\
\hline
\end{tabular}

Table 2 List of keywords of Chinese building

\section{CARPENTRY TECHNOLOGY KNOWLEDGE ANALYSIS AND RESEARCH}

The Taiwan traditional building mainly shows the building form and structure by the carpentry technology, which comes from southern Fujian for early migrants of Taiwan who brought this technology to Taiwan. Hundreds of years later, this technology is considered as an invisible asset from the view of cultural asset. This technology has the following related sciences: building science, history science, fortune science, religion science, structure mechanics, tectonics, material science, management science, disaster-resistance science. Relative to the $\lceil$ carpentry technology knowledge 」, it integrates all sciences cross the fields, researches the research results in all fields, and integrates the core theories of sciences and actual practice of research results.

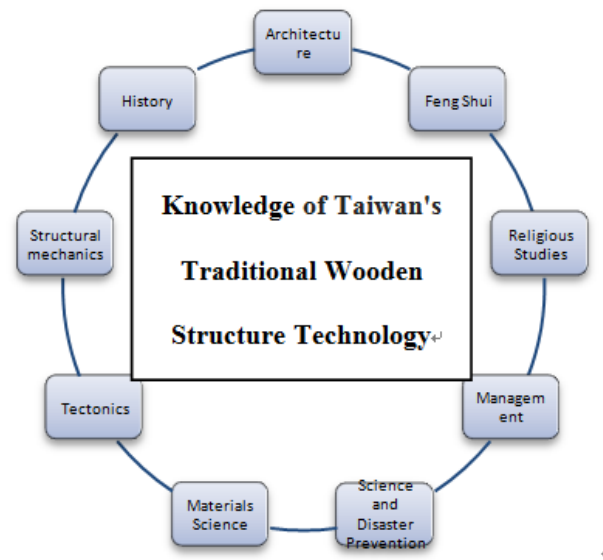

Figure 1 Science scope of traditional building carpentry technology

\subsection{Carpentry technology knowledge classification}

The wooden structure of Taiwan traditional building is performed by the carpentry technology, the traditional building in the past is focused on 「newly building $\rfloor$ from nothing to something, as time goes by, the building shows more [repair] now, the existing building is repaired by reverse construction method, therefore, as to the carpentry technology knowledge, there are two parts: $\lceil$ traditional building newly building knowledge $\rfloor$ and $\lceil$ traditional building repair knowledge $\rfloor$. However, there are many wide-sense researches on carpentry technology, but this research will centralize the research purpose and follow the query website of 「Taiwan master and doctor paper value-adding system $\rfloor$. The query is made according to the name and keywords in the search system in terms of the $\lceil$ carpentry $\rfloor$ keywords, and there are 49 papers (up to July 10, 2015) , including 42「 carpentry 」 related research papers, which are primarily classified into five research topics:

1. Research on traditional building construction technology

2. Research on carpentry craftsman works and technology

3. Research on pole falling technology, building taboo and form

4. Research on traditional building repair science

5. Research on traditional building carpentry

The literature research direction of carpentry technology can be seen from the aforementioned data, however, the integral knowledge framework should also be understood by interview, as to the traditional knowledge, the interviewee M2 shows $\lceil$ a carpentry craftsman has to have the technical skills of wood selection, amount calculation, wood use and knowledge, basic production, manual tool production, repair and maintenance, form taboo, calculation method of white size, space concept and structure aesthetics, more important, the training in ratio and material property handling $\rfloor$, meanwhile, as to the repair knowledge, the interviewee M4 shows 「before the repair construction, it is necessary to know the drawing, understand the construction plan, keep the wood dry, check and repair the tool; during the construction, it is necessary to fall and decompose the component, number the component, repair and old wood, process new material, and assemble the material $\rfloor$, therefore, according to the literature reference and description 
from interviewee, the knowledge of traditional building carpentry technology can be divided into five categories:

1. Building plan

2. Building technology

3. Construction plan

4. Repair science

5. Building history view

\subsection{Carpentry technology layering framework}

The knowledge framework is formed by certain composition ways and proportion, composed of all knowledge and featured with open, dynamic, common and multi-level, the carpentry knowledge has been primarily classified, so it is possible to establish the knowledge framework and perform layer analysis. The layer framework in this research is divided into four layers. The first layer is the carpentry technology knowledge system framework, the second layer is the building plan, building technology, building plan, repair science, building history view, and the detail division of all layers are shown in Table 3.

\begin{tabular}{|c|c|c|c|}
\hline First layer & $\begin{array}{c}\text { Second } \\
\text { layer }\end{array}$ & $\begin{array}{l}\text { Third } \\
\text { layer }\end{array}$ & Fourth layer \\
\hline \multirow{10}{*}{$\begin{array}{l}\text { Carpentry } \\
\text { technology } \\
\text { knowledge } \\
\text { system } \\
\text { framework }\end{array}$} & \multirow{5}{*}{$\begin{array}{l}\text { A. } \\
\text { Building } \\
\text { plan }\end{array}$} & $\begin{array}{l}\text { A1 space } \\
\text { and shape } \\
\text { design }\end{array}$ & $\begin{array}{l}\text { A1-1 place with } \\
\text { good fortune } \\
\text { A1-2 layout } \\
\text { configuration }\end{array}$ \\
\hline & & $\begin{array}{l}\text { A2 size } \\
\text { plan }\end{array}$ & $\begin{array}{l}\text { A2-1 size plan } \\
\text { A2-2 size fortune }\end{array}$ \\
\hline & & $\begin{array}{l}\text { A3 wood } \\
\text { selection }\end{array}$ & $\begin{array}{l}\text { A3-1 wood type } \\
\text { A3-2 wood property } \\
\text { A3-3 material } \\
\text { calculation }\end{array}$ \\
\hline & & $\begin{array}{l}\text { A4 cost } \\
\text { budget }\end{array}$ & $\begin{array}{l}\text { A4-1 cost } \\
\text { calculation } \\
\text { A4-2 expenditure } \\
\text { calculation }\end{array}$ \\
\hline & & $\begin{array}{l}\text { A5 } \\
\text { constructi } \\
\text { on } \\
\text { managem } \\
\text { ent }\end{array}$ & $\begin{array}{l}\text { A5-1 construction } \\
\text { supervision } \\
\text { A5-2 safety and } \\
\text { protection } \\
\text { A5-3 environment } \\
\text { and sanitation } \\
\text { A5-4 quality } \\
\text { management } \\
\text { A5-5 manpower } \\
\text { scheduling }\end{array}$ \\
\hline & \multirow{5}{*}{$\begin{array}{l}\text { B. } \\
\text { Building } \\
\text { technolo } \\
\text { gy }\end{array}$} & $\begin{array}{l}\text { B1 tool } \\
\text { operation } \\
\text { and } \\
\text { maintenan } \\
\text { ce }\end{array}$ & $\begin{array}{l}\text { B1-1 manual tool } \\
\text { B1-2 electric tool }\end{array}$ \\
\hline & & $\begin{array}{l}\text { B2 } \\
\text { constructi } \\
\text { on } \\
\text { material }\end{array}$ & $\begin{array}{l}\text { B2-1 material } \\
\text { property } \\
\text { B2-2 material } \\
\text { preparation and } \\
\text { production }\end{array}$ \\
\hline & & $\begin{array}{l}\text { B3 } \\
\text { building } \\
\text { structure }\end{array}$ & $\begin{array}{l}\text { B3-1 structure form } \\
\text { design } \\
\text { B3-2 structure } \\
\text { power calculation }\end{array}$ \\
\hline & & $\begin{array}{l}\text { B4 } \\
\text { constructi } \\
\text { on } \\
\text { procedure }\end{array}$ & $\begin{array}{l}\text { B4-1Newly built } \\
\text { project } \\
\text { B4-2 repair project }\end{array}$ \\
\hline & & $\begin{array}{l}\text { B5 } \\
\text { constructi }\end{array}$ & $\begin{array}{l}\text { B5-1Newly built } \\
\text { project }\end{array}$ \\
\hline
\end{tabular}

\begin{tabular}{|c|c|c|}
\hline & on skill & B5-2 repair project \\
\hline & $\begin{array}{l}\text { B6 } \\
\text { structure } \\
\text { constructi } \\
\text { on }\end{array}$ & $\begin{array}{l}\text { B6-1 girder } \\
\text { production } \\
\text { B6-2 post } \\
\text { production } \\
\text { B6-3 mortise } \\
\text { production } \\
\end{array}$ \\
\hline \multirow[b]{2}{*}{$\begin{array}{l}\text { C. } \\
\text { Building } \\
\text { rule }\end{array}$} & $\begin{array}{l}\mathrm{C} 1 \\
\text { building } \\
\text { tradition }\end{array}$ & $\begin{array}{l}\text { C1-1 punt-pole } \\
\text { production } \\
\text { C1-2 building taboo } \\
\text { C1-3 building form } \\
\text { C1-4building pithy } \\
\text { formula }\end{array}$ \\
\hline & $\begin{array}{l}\text { C2 } \\
\text { occupatio } \\
\text { nal theory }\end{array}$ & $\begin{array}{l}\text { C2-1 legal } \\
\text { regulations } \\
\text { C2-2 working } \\
\text { regulations } \\
\text { C2-3 repair } \\
\text { regulations } \\
\text { C2-4 } \\
\text { professionalism } \\
\end{array}$ \\
\hline \multirow{3}{*}{$\begin{array}{l}\text { D. } \\
\text { Repair } \\
\text { science }\end{array}$} & $\begin{array}{l}\text { D1 repair } \\
\text { theory }\end{array}$ & $\begin{array}{l}\text { D1-1 repair theory } \\
\text { and concept } \\
\text { D1-2 repair } \\
\text { technical } \\
\text { knowledge } \\
\text { D1-3 repair laws } \\
\text { and regulations }\end{array}$ \\
\hline & $\begin{array}{l}\text { D2 wood } \\
\text { science }\end{array}$ & $\begin{array}{l}\text { D2-1 wood physical } \\
\text { and chemical use } \\
\text { D2-2 wood } \\
\text { organization and } \\
\text { authentication } \\
\text { D2-3 wooden } \\
\text { environment } \\
\text { D2-4 wood drying } \\
\text { and storage } \\
\text { D2-5 wood gluing } \\
\text { and coating } \\
\text { D2-6 wood } \\
\text { composite material }\end{array}$ \\
\hline & $\begin{array}{l}\text { D3 } \\
\text { disaster- } \\
\text { resistance } \\
\text { science }\end{array}$ & $\begin{array}{l}\text { D3-1 pest and insect } \\
\text { resistance } \\
\text { D3-2 earthquake } \\
\text { disaster resistance } \\
\text { D3-3 fire disaster } \\
\text { resistance } \\
\text { D4-4 flood disaster } \\
\text { resistance }\end{array}$ \\
\hline \multirow[t]{2}{*}{$\begin{array}{l}\text { E. } \\
\text { Building } \\
\text { history } \\
\text { view }\end{array}$} & $\begin{array}{l}\text { E1 Taiwan } \\
\text { building } \\
\text { history }\end{array}$ & $\begin{array}{l}\text { E1-1 building of } \\
\text { Aboriginal } \\
\text { E1-2 building in } \\
\text { Jose period } \\
\text { E1-3 Chinese } \\
\text { building } \\
\text { E1-4 Japanese } \\
\text { building } \\
\text { E1-5 Western } \\
\text { building } \\
\text { E1-6 Modern } \\
\text { building }\end{array}$ \\
\hline & $\begin{array}{l}\text { E2 Taiwan } \\
\text { traditional } \\
\text { building } \\
\text { type }\end{array}$ & $\begin{array}{l}\text { E2-1 city building } \\
\text { E2-2 culture and } \\
\text { education building } \\
\text { E2-3 temple } \\
\text { building }\end{array}$ \\
\hline
\end{tabular}




\begin{tabular}{l|l|l}
\hline \multirow{2}{*}{} & & $\begin{array}{l}\text { E2-4 house building } \\
\text { E2-5 garden } \\
\text { building }\end{array}$ \\
\cline { 3 - 4 } & & $\begin{array}{l}\text { E3-1 craftsman } \\
\text { character works } \\
\text { E3-2 craftsman } \\
\text { characteristics } \\
\text { E3 Taiwan } \\
\text { carpentry } \\
\text { technolog } \\
\text { y history }\end{array}$ \\
& $\begin{array}{l}\text { E3-3 craftsman } \\
\text { industry evolution } \\
\text { E3-4 tool use } \\
\text { evolution }\end{array}$ \\
\hline
\end{tabular}

Table 3 Knowledge system framework of carpentry technology

\section{CONCLUSION AND SUGGESTION}

The establishment of knowledge system of Taiwan traditional building carpentry technology mainly aims to understand the research direction, knowledge framework and knowledge level of this knowledge system. This research hopes to extend correct knowledge according to the description of technology knowledge and theoretical basis and industrial development direction under the influence of times fault on talent, so this research gets the following conclusion and suggestion:

\subsection{Establish the knowledge system framework of carpentry technology}

The knowledge of carpentry technology is extremely wide. This research performs professional knowledge analysis by related data record and expert interview and has primarily planned the integral framework. The expansion and depth of the knowledge system can be expanded according to the to-be-set condition and is expected to be built in current research framework to gradually complete the knowledge system and classify related knowledge. Besides, the carpentry technology is one of Taiwan building construction and repair technologies and can continuously establish the knowledge systems of other technologies to combine all knowledge systems as the knowledge system of Taiwan buildings, digitize the knowledge skill and digitize the operation technology, which is helpful for storing and managing the building knowledge and technology and extends to the following function basic establishment, function course plan, talent training, occupational ability authentication, and establishes a set of training, examination and use complete system of the traditional building repair technology.

\subsection{Link the knowledge systems as a knowledge base system}

This research has carried out primary framework classification to the carpentry technology knowledge system and finished the term definition of core technical abilities. Converting these technical abilities into knowledge can expand more knowledge which can be used as the form construction of [knowledge base system of carpentry technology] and as one of [technology storage] ways to conclude the data of knowledge data as the [annotation data] and the [authority document]; the content of core technical abilities can be integrated as a whole part and used as important annotation data, thus preventing incorrect technical ability due to lost or misunderstood technology, whereas, the authority control design of [authority document] mainly aims to generate quick index for the data in specific field and continuously keep the collectivity, compatibility, associativity and stability of words group in the condition of continuously adding data according to the rules and target of authority control design. Using the aforementioned ways to standardize the knowledge and set the authority document is considered as a technical specification to standardize the technology and prevent loss or torsion.

\section{REFERENCES}

Xu Yujian, 1980. Study on regulation of construction size of Taiwan architecture (Unpublished doctoral master's thesis). National Cheng Kung University Institute of Architecture, Tainan, Taiwan.

Mishler,1986. Elliot G. Research Interviewing: Context and Narrative, Cambridge, MA: Harvard University Press.

Li Ganlang, 1988. Survey research on school of traditional construction craftsman, Cultural Affairs, Taipei, Taiwan.

Xu Mingfu, 1990. Study on dwelling house of Taiwan traditional architecture and its local historical data, Hu Books, Taipei, Taiwan.

Hong Wenxiong,1991. Survey research on traditional craftsman in Taiwan and Fujian (phase I), Ministry of the Interior, Taipei, Taiwan.

Hong Wenxiong,1993. Survey research on traditional craftsman in Taiwan and Fujian (phase II), Ministry of the Interior, Taipei, Taiwan.

Lin Huicheng, 1995. Manual of Taiwan Traditional ArchitectureForm and Practice, Artist Publishing, Taipei, Taiwan.

Harris,D.B., 1996. Creating a knowledge centric information technology environment. Harris Training \& Consulting Services Inc., Seattle, WA.

Li Ganlang, 1999. Traditional pole falling technology in Taiwan and Fujian. Taiwan's traditional architecture Craftsmanship two series, Martin House Ancient Architectural Press, Taipei, Taiwan.

Lin Huicheng, 2001 . Construction of architectural history in Taiwan: seven culture periods and five orientations. Taiwan literature. Taiwan literature, 52(3),pp.231-279.

Zhang Yutong, 2001. Comparative study on shape of traditional dwelling house in Jinmen and Penghu-Discussion on taboo, ceremony and decoration during construction. (Unpublished doctoral doctoral dissertation). National Cheng Kung University Institute of Architecture, Tainan, Taiwan.

G. Tomas M. Hult, 2003. An Integration of Thoughts on Knowledge Management, A Journal Of The Decision Sciences Institute, 34, 189-385.

Li Ganlang,2003.Encyclopedia on diagram of ancient architecture in Taiwan. Yuan-Liou Publishing, Taipei, Taiwan.

Xu Mingfu, 2004. Compilation plan on handbook of vocabulary on historical sites (ancient architectures) and historical architecture. National Preservation Center Preparatory Office of Cultural Assets, Tainan, Taiwan.

Lai Zhizhang, 2007.Survey on traditional craftsman for preservation and repair of buildings.cultural assets and study on cultivation strategy. Council for Cultural Affairs Cultural Assets General Administration Preparatory Office, Taichung, Taiwan.

Lin Yijun, 2009.Feasibility study on representation of pole of Taiwan traditional timber structure with digital mode . National Cheng Kung University Institute of Architecture, Tainan, Taiwan.

Xue Qin, 2010. Plan on maintenance of historical sites, historical architecture and settled cultural landscape and human resource protection of repair craftsman. Council for Cultural Affairs Cultural Assets General Administration Preparatory Office, Taichung, Taiwan. 